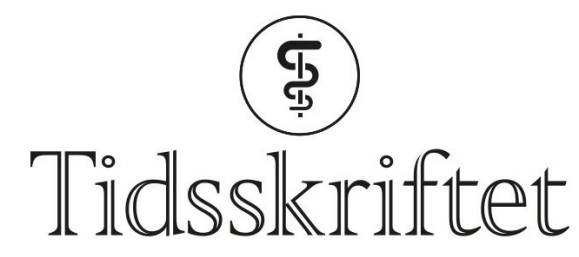

DEN NORSKE LEGEFORENING

\title{
RP: Ren luft
}

MINILEDER

ARE BREAN

Sjefredaktør

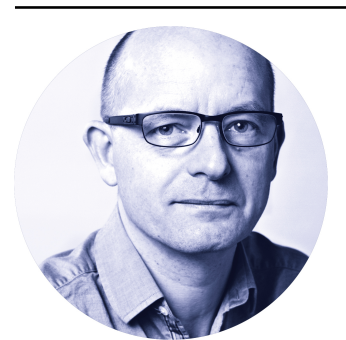

Verdens helseorganisasjon har nylig publisert rapporten Air pollution and child health: prescribing clean air. Det er ikke uten grunn "forskrivning av ren luft» brukes som undertittel i rapporten. $93 \%$ av verdens barn puster i luft som er så forurenset at det setter deres liv og helse i fare. Luftforurensning fører til reduserte kognitive evner, er koblet til utvikling av astma og barnekreft og gir økt risiko for senere kardiovaskulær sykdom, alt ifølge rapporten.

Totalt forårsaket luftforurensning 4,2 millioner premature dødsfall i 2016, med fossilt brennstoff som den globale verstingen. Mest utsatt er befolkningen i lavinntektsland. Men heller ikke i Norge har vi grunn til å slå oss selvtilfreds på brystet. Norge er dømt i EFTAdomstolen for omfattende lokal luftforurensning. Hvert år brytes de fastsatte grensene for luftkvalitet i norske byer, med veitrafikk som den største forurensningskilden. Når vi nå går mot en ny vinter, er det grunn til å minne om at ethvert tiltak for å minske biltrafikken i byene er et effektivt folkehelsetiltak, særlig for barna.

Publisert: 13. november 2018. Tidsskr Nor Legeforen. DOI: 10.4045/tidsskr.18.18.01

(C) Tidsskrift for Den norske legeforening 2020. Lastet ned fra tidsskriftet.no 